\title{
Red Wave: Improving Care to Severe Trauma Victims
}

\author{
${ }^{1}$ Ana C Romeo, ${ }^{2}$ Andre G Cunha, ${ }^{3}$ Pedro S Filho, ${ }^{4}$ Victor Oliveira, ${ }^{5}$ Thiago Moura, ${ }^{6}$ Jorge Motta \\ ${ }^{7}$ Gustavo Mendes, ${ }^{8}$ Marcio R Cruz
}

\begin{abstract}
Objectives: To describe the results of a systematic, rapid, and effective method of communication for the definitive treatment of patients with severe traumatic bleeding.
\end{abstract}

Materials and methods: The Red Wave was developed to improve communication between the emergency department and other strategical processes and to reduce the time from the arrival of severe traumatic hemorrhagic patient to a definitive treatment in the operating room.

On admission, the traumatized patient is seen by the nursing staff in the Red Room, who trigger a general bell indicating the arrival of a severe trauma patient.

The surgeon activates the red bell, which triggers an audible and visual alarm at strategic sectors of the hospital: operating center, transfusional agency, and laboratory, each one with its established sub-protocol. We defined as goals that the patient must arrive at the operating room in a maximum of 15 minutes after the Red Wave activation, with availability of blood and plasma in 20 minutes and blood tests collected at the same time. A light panel located in the surgical center turns off at each completed step, recording their time-responses.

Results: From June through December 2015, we admitted 831 trauma patients in the Red Room of Hospital do Suburbio, predominantly young (67.9\% younger than 40 years old) and male $(77.5 \%)$. Blunt trauma was the predominant mechanism $(79.2 \%)$, and the majority of patients had an revised trauma score (RTS) calculated at admission greater than 7 (86.5\%).

We also evaluated, from September through December 2015 , the attendance of 96 patients admitted with a diagnosis of hemorrhagic traumatic shock. The Red Wave was triggered in $39.6 \%$ of these cases. Gunshot wounds were the most frequent mechanism of trauma (86.5\%), with a survival rate of $56.8 \%$.

The goals for time-responses were met in most of the cases, with correctness of $81.6 \%$ for the patient arrival at the operating room, $81.6 \%$ for laboratory sampling, and $86.8 \%$ for blood and plasma availability by the transfusion agency.

Conclusion: The Red Wave proved to be an effective protocol to systematize the initial treatment of patients with severe traumatic bleeding, improving communication between the strategic sectors involved, reducing the time-response of each service and making the definitive treatment of these patients faster and suitable.

Keywords: Hemorrhagic shock, Red wave, Trauma care.

\footnotetext{
${ }^{1,2,8}$ Professor, ${ }^{3,4}$ Student, ${ }^{5-7}$ Consultant

${ }^{1-8}$ Department of General Surgery, Hospital do Subúrbio Salvador, Bahia, Brazil

Corresponding Author: Ana C Romeo, Professor, Department of General Surgery, Hospital do Subúrbio, Salvador, Bahia, Brazil Phone: +5571999714547, e-mail: anaceliaromeo@gmail.com
}

How to cite this article: Romeo AC, Cunha AG, Filho PS, Oliveira V, Moura T, Motta J, Mendes G, Cruz MR. Red Wave: Improving Care to Severe Trauma Victims. Panam J Trauma Crit Care Emerg Surg 2017;6(3):155-159.

Source of support: Nil

Conflict of interest: None

\section{RESUMO}

Objetivo: Descrever resultados de meio de comunicação sistemático, rápido e efetivo para tratamento definitivo de pacientes com trauma hemorrágico grave.

Materiais e métodos: A Onda Vermelha foi desenvolvida para melhorar a comunicação entre o departamento de emergência e outros setores estratégicos do hospital e reduzir o tempo entre a chegada do paciente com trauma hemorrágico grave e o tratamento cirúrgico definitivo.

O paciente traumatizado é avaliado na admissão pela enfermagem responsável pela sala vermelha que ativa campainha indicando a chegada de paciente traumatizado grave.

O cirurgião após avaliação do paciente aciona uma campainha vermelha que dispara um sinal sonoro e visual em setores estratégicos do hospital, cada um com seus subprotocolos preestabelecidos. Definimos como objetivos a chegada do paciente ao centro cirúrgico em 15 minutos após o acionamento da Onda Vermelha, havendo disponibilidade de concentrado de hemácias e plasma fresco congelado e coleta de exames laboratoriais em 20 minutos. Uma luz do painel luminoso no centro cirúrgico apaga a cada etapa completada, gravando os tempos de resposta.

Resultados: Entre Junho e Dezembro de 2015, 831 pacientes traumatizados foram admitidos na sala vermelha do Hospital do Subúrbio, predominantemente jovens ( $67,9 \%$ com menos de 40 anos) do gênero masculino (77,5\%). O trauma contuso foi o mecanismo mais frequente $(79,2 \%)$ e a maioria dos pacientes tiveram o RTS calculado na admissão maior que 7 (86,5\%).

Avaliamos ainda, entre Setembro e Dezembro de 2015, o atendimento de 96 pacientes admitidos com choque hemorrágico traumático. A Onda Vermelha foi ativada em 39.6\% destes casos. Ferimentos por arma de fogo foram mais frequentes nestes $(86,5 \%)$, com uma taxa de sobrevida de $56,8 \%$.

Os objetivos de tempo foram alcançados na maioria dos casos: $81,6 \%$ na chegada do paciente ao centro cirúrgico e coleta do laboratório e $86,8 \%$ na disponibilidade do concentrado de hemácias e plasma pela agência transfusional.

Conclusão: A Onda Vermelha mostrou-se protocolo efetivo para sistematização do tratamento inicial do paciente com choque hemorrágico, melhorando a comunicação entre os setores estratégicos envolvidos, reduzindo o tempo de resposta de cada setor e tornando o tratamento destes pacientes adequado e ágil.

Palavras-chave: Atendimento ao trauma, Choque hemorrágico, Onda Vermelha.

Presented in the General Competetion, PTS Congress, Maceio, Brazil in November 2016 


\section{INTRODUCTION}

Trauma fullfills the disease classification criteria for a global pandemia and it is a significant cause of morbidity and mortality over the years and across the continents, despite all the efforts to control it. Worldwide more than 5 million people die per year and the numbers are increasing. ${ }^{1,2}$

Since the opening of Hospital do Subúrbio, the number of admissions motivated by external causes increased progressively, from 2.287 patients in 2010 to 4.218 patients in 2015 . The main reason of adult's hospitalizations in 2015 was the major trauma (33.6\%), corresponding to $10.9 \%$ of hospital deaths. ${ }^{3}$

Considering the data, in order to improve communication between the emergency department and other strategical processes of our Institution and to reduce the time from the arrival of severe traumatic hemorrhagic patients to a definitive treatment in the operating room we developed, based on the protocol of the Red Wave from the João XXIII Hospital at Belo Horizonte - MG - Brazil, ${ }^{4}$ our own Red Wave protocol adapted to the characteristics of our Hospital.

\section{MATERIALS AND METHODS}

On admission, the traumatized patient is attended by the nursing staff in the Red Room, who perform a quick and simplified assessment of the RTS parameters. ${ }^{5}$ Any other parameter than normal can indicate a moderate or a severe trauma patient and a general bell is triggered warning about the arrival of such patient.

The general surgeon assessment is made with emphasis on the diagnosis of severe hemorrhagic shock (classes III and IV). ${ }^{6}$ which was systematized according to the assesment of blood consumption (ABC) score. ${ }^{7}$ originally used for indication of massive transfusion.

In positive cases, the surgeon activates the red bell, which triggers an audible and visual alarm to strategic sectors of the hospital: surgical center, transfusional agency and laboratory, each one with its established sub-protocol. We defined as goals: (1) The patient must arrive at the operating room in a maximum of 15 minutes after the activtion of the Red Wave, (2) the transfusional agency provides blood and plasma in 20 minutes, and (3) blood tests are collected at the same time. A light panel located in the surgical center turns off at each completed step, recording their time-responses.

\section{RESULTS}

From June through December 2015, we admitted 831 trauma patients in the Red Room of Hospital do Suburbio, predominantly young $(67.9 \%$ younger than 40 years old) and male $(77.5 \%)$. Blunt trauma was the predominant mechanism $(79.2 \%)$, being road traffic crashes $(68.39 \%)$, specially motorcycle ones, more common. Most patients had an RTS, calculated at admission, greater than 7 $(86.5 \%)$. The victims of penetrate trauma had lower RTS comparing to blunt trauma ones (7.22 vs 7.54).

Among those, 96 patients were admitted with diagnosis of hemorrhagic traumatic abdomen. The Red Wave was triggered in $39.6 \%$ of these cases, with correctness of $78.9 \%$, according to established parameters. Gunshot wounds were most frequent mechanism of trauma $(86.5 \%)$, with survival rate of $56.8 \%$.

The goals for time-responses were met in most cases, with correctness of $81.6 \%$ for the patient arrival to the operating room, $81.6 \%$ for laboratory sampling and $86.8 \%$ for blood and plasma availability by the transfusion agency.

\section{DISCUSSION}

Trauma is an important cause of death and disabilities all over the world and the projections for 2020 show that 8.4 million death per year are expected. ${ }^{1}$ In our environment, we have been witnessed a great number of emergency visits and hospital admissions for this reason.

This study confirms the world epidemiological data that trauma is a disease that predominantly affects younger males. ${ }^{7}$ The Hospital do Subúrbio is established at the Metropolitan Region of Salvador, Bahia, Brazil, an area where interpersonal violence and firearms are more commonly used, ${ }^{8,9}$ explaining the high number of victims of gunshot wounds, arriving in hemorrhagic shock.

Many sudies have shown that an organized system of trauma care is essential in reducing disabilities and mortality resulting from trauma. ${ }^{10,11}$ Establishing the protocol, training the staff, defining the goals and reassessing are important steps to systematize care .

In order to improve the diagnostic of hemorrhagic shock, the ABC score, developed to predict massive comsumption early, was chosen. It is assigned based on the four parameters: (1) penetrating mecanism, (2) positive focused assessment sonography for trauma, (3) arrival systolic pressure of $90 \mathrm{~mm} \mathrm{Hg}$ or less, and (4) arrival heart rate higher than or equal to $120 \mathrm{bpm}$. Two of these criteria trigger the Red Wave. Our study shows that, according to established parameters, it happened in $39.6 \%$ of cases, with correctness of $78.9 \%$, revealing how important is for the protocol recognize shock. ${ }^{7}$

Most patients had an RTS calculated at admission greater than $7(86.5 \%)$. The victims of penetrate trauma had lower RTS comparing to blunt trauma victims (7.22 vs 7.54). Despite high RTS index, predicting a high rate of survival on admission, our survival rate was $56.8 \%$. We conclude the necessity of implementing the injury severity score trauma index, which takes into account the 
anatomical injuries and correlates better to late survival rates. $^{12}$

The patient must arrive at the operating room in 15 minutes minimizing the time elapsed between injury and operation for urgent bleeding control. More than $50 \%$ of all trauma patients die because of an uncontrolled bleeding. ${ }^{6}$ The surgery center must provide an operating room with an temperature over $24^{\circ} \mathrm{C}$, warm crystalloid solutions and adequate surgical instruments for laparotomy and thoracotomy. We achieved this goal in $81.6 \%$ of the time.

Major trauma results not only in bleeding from anatomical sites but also frequently in coagulopathy, which is associated with increase in mortality. ${ }^{13,14}$ This early coagulopathy is found in patients with hypoperfusion increasing international normalized ratio and activated partial thromboplastin time (APTT) and lowering calcium, platelets, and fibrinogen. Although there is little direct evidence for the effect of these measures, it is recommended that monitoring and support coagulation be initiated as early as possible. We managed to collect blood sampling early in $81.6 \%$ of the time.

Erythrocytes contributes to hemostasis and improves tissular and cerebral oxigenation and fresh frozen plasma is recommended when prothrombin time and APTT are 1.5 times control or after red blod cells transfusion in ratios of $1: 1{ }^{15,16}$ Our study reveals that in $86,8 \%$ of time the fresh frozen plasma and red blood cells were available for use, supplying any needs.

This study demostrates the theoretical fundamentals to implement a protocol and organize care of major trauma patients in order to increase survival rates and decrease disabilities. We present our initial data aiming to compare to our future results and to the literature improving our results.

\section{CONCLUSION}

The ability to respond quickly and effectively is essential to improve survival. The way how communication occurs between the emergency, the surgery center, the laboratory and the transfusional agency and how each one is aware of their own role give the emergency team suitable conditions to take better care of the patients.

\section{REFERENCES}

1. Krug EG, Sharma GK, Lozano R. The global burden of injuries. Am J Public Health 2000 Apr;90(4): 523-526.

2. World Health Organization (WHO). Injuries. 2014. Available from: http://www.who.int/topics/injuries/en/

3. Hospital do Subúrbio. III Boletim epidemiológico 2014-2015.

4. Drummond DAF, Vieira Jr HM. Protocolos em trauma - Hospital de Pronto Socorro João XXIII. 1 ed. 2009.

5. Champion HR; Sacco WJ; Copes WS; Gann DS; Gennarelli TA, Flanagan ME. A revision of the trauma score. J Trauma 1989 May;29(5):623-629.

6. Colégio Americano de Cirurgiões. Suporte avançado de vida no trauma: programa para médicos. 8 ed. 2008.

7. Nunez TC, Voskresensky IV, Dossett LA, Shinall R, Dutton $\mathrm{WD}$, Cotton BA. Early prediction of massive transfusion in trauma: simple as ABC (assesment of blood consumption)? J Trauma 2009 Feb;66(2):346-352.

8. Lyons RA, Jones SJ, Deacon T, Heaven M. Socioeconomic variation in injury in children and older people: a population based study. Inj Prev 2003 Mar;9:33-37.

9. Ribeiro LM. Pesquisa sobre crimes de homicídios na Bahia. Em Pastoral da Paz. A outra face da moeda. Os dado da violência RMS. Salvador: Pastoral da Paz; 2000.

10. Teixeira PGR, Inaba K, Hadjizacharia P, Brown C, Salim A, Rhee P, Browder T, Noguchi TT, Demetriades D. Preventable or potentially preventable mortality at a mature trauma center. J Trauma 2007 Dec;63(6):1338-1347.

11. Sanddal TL, Esposito TJ, Whitney JR, Hartford D, Taillac PP, Mann NC, Sanddal ND. Analysis of preventable trauma deaths and opportunities for trauma care improvement in Utah. J Trauma 2011 Apr;70(4):970-977.

12. Baker SP; O'Neill B; Haddon W Jr, Long WB. The injury severity score: a method for describing patients with multiple injuries and evaluating emergency care. J Trauma 1974 Mar;14(3): 187-196.

13. MacLeod JB, Lynn M, McKenney MG, Cohn SM, Murtha M. Early coagulopathy predicts mortality in trauma. J Trauma 2003 Jul;55(1):39-44.

14. Brohi K, Singh J, Heron M, Coats T. Acute traumatic coagulopathy. J Trauma 2003 Jun;54(6):1127-1130.

15. Rossaint R, Bouillon B, Cerny V, Coats TJ, Duranteau J, Fernández-Mondéjar E, Hunt BJ, Komadina R, Nardi G, Neugebauer E, et al: Management of bleeding following major trauma: an updated European guideline. Crit Care 2010;14(2):R52.

16. Snyder CW, Weinberg JA, McGwin GJr, Melton SM, George RL, Reiff DA, Cross JM, Hubbard-Brown J, Rue LW 3rd, Kerby JD. The relationship of blood product ratio to mortality: survival benefit or survival bias? J Trauma 2009 Feb;66(2): 358-364. 


\section{Red Wave: Improving Care to Severe Trauma Victims}

Trauma is the leading cause of death for young adults all around the world and all measures that can reduce this statistic should be implemented and disseminated. Trauma prevention is the most important and most effective way to reduce the alarming numbers of trauma. However, once the traumatic event has occurred, adequate care in all phases of care will make a significant difference in the outcome.

The early identification of all the resources demanded by the patient and the availability of these will increase the chances of patient's survival. Among these resources, shock treatment is a constant and its adequate management will impact early and late mortality.

The Red Wave strategy presented by the authors is interesting and allows the optimization of the shock treatment through early availability of blood components and transfer to the definitive treatment in the operating room at the right time, thus avoiding the lethal triad.

In countries, such as Brazil, where trauma systems and their components are in the implementation process, all the tools that disseminate trauma care protocols make a difference and reinforce the need for integration among all sectors that are directly related to this care.

As reported in this manuscript, the number of victims of external causes increases each year and aggressive measures are taken to optimize resources.Protocols, such as this, involve all teams that are part of trauma care. The more integrated the team that acts at some point in the care, either in the emergency room or in the operating room, the better the results for these patients.

The evaluation of these results will allow the identification of the fragilities of the protocol to increase its effectiveness, and to collaborate in reducing the mortality and morbidity of the traumatized patient.

Cristiane de Alencar Domingues

Faculdade das Américas Programa ATCN na América Latina 


\section{INVITADO COMENTARIO}

\section{Red Wave: Melhorando o Cuidado para Vítimas de Trauma Severas}

O trauma é a principal causa de morte em adultos jovens ao redor do mundo, e todas as medidas que reduzem essa estatística devem ser implementadas e disseminadas. A prevenção do trauma é a principal e mais eficaz estratégia para diminuir os números alarmantes do trauma. No entanto, uma vez que o evento traumático ocorreu, tratamento adequado em todas as fases do cuidado fará a diferença no resultado.

A identificação precoce de todos os recursos exigidos pelo paciente e a disponibilidade destes aumentará a sobrevida do paciente. Entre esses recursos, o tratamento do choque é uma constante e sua adequada gestão interferirá na mortalidade precoce e tardia.

A estratégia Red Wave apresentada pelos autores é interessante e permite a otimização do tratamento do choque por meio da disponibilidade precoce de componentes sanguíneos e transferência para o tratamento definitivo no momento certo, evitando-se, assim, a tríade letal.

Em países como o Brasil, onde os sistemas de trauma e seus componentes estão no processo de implementação, todas as ferramentas que disseminam a cultura dos protocolos de atendimento ao trauma fazem a diferença e reforçam a necessidade de integração entre todos os setores que estão diretamente relacionados a esse cuidado.

Como pode ser visto no trabalho, o número de vítimas de causas externas aumenta a cada ano e medidas agressivas precisam ser tomadas no sentido de otimizar os recursos que nem sempre estão empregados da melhor maneira possível.

Além disso, protocolos como este envolvem todas as equipes que fazem parte do atendimento ao traumatizado. Quanto mais integrada for a equipe que atua em algum momento da assistência, quer no pronto socorro ou no centro cirúrgico, melhores serão os resultados para esses doentes.

A avaliação desses resultados permitirá o levantamento das fragilidades do protocolo para aumentar sua efetividade, e colaborar na diminuição da mortalidade e morbidade do doente traumatizado.

Cristiane de Alencar Domingues

Faculdade das Américas

Programa ATCN na América Latina 